\section{Ks. Maciej Basiuk}

Uniwersytet Śląski, Katowice

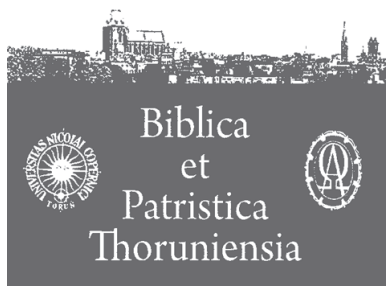

2 (2009)

\title{
Rola Księgi proroka Jonasza w nauczaniu św. Ambrożego
}

Ambroży jako biskup Mediolanu bardzo poważnie traktował swoją posługę, która polegała na trosce o powierzony mu lud. Wyrażała się ona m.in. w kazaniach, które kierował do swoich diecezjan przy różnych okazjach. Były one bardzo mocno oparte na Piśmie Świętym. Biblia była dla niego narzędziem, które pomagało mu w tej trosce pasterskiej ${ }^{1}$. Jego podejście do Pisma Świętego dobrze ilustrują jego własne słowa: „Posilajmy się więc chlebem mądrości i nasycajmy słowem Bożym, ponieważ nie samym chlebem, lecz wszelkim słowem Bożym żyje człowiek, stworzony na obraz i podobieństwo Boże"2. Według Krzysztofa Bardskiego, gdyby zebrać wszystkie aluzje do tekstów biblijnych z pism Ambrożego, to otrzymalibyśmy interpretację obejmującą prawie wszystkie wersety Pisma Świętego ${ }^{3}$.

Biskup Mediolanu troszczył się również o to, aby jego słuchacze otrzymali właściwą interpretację tekstu biblijnego. Grono jego odbiorców było bardzo różnorodne. Byli wśród nich ludzie prości i bardzo wykształceni, byli poszukujący oraz ugruntowani w swojej wierze. Dlatego Ambroży w swoich kazaniach bardzo konsekwentnie tłumaczy wszelkie trudniejsze pojęcia, ale jednocześnie nie unika odniesień do dzieł filozofów starożytnych czy też poglądów współczesnych mu myślicieli ${ }^{4}$. Jak pisze Charles Kannengiesser, w centrum działalności Ambrożego przez całe życie pozostawało „przemyśleć samemu i dzielić z współczesnymi sobie chrześcijanami całe swoje rozumienie Kościoła i świata, szczególnie w odniesieniu do Pisma Świętego"'.

1 K. Bardski, Słowo oczami gołębicy. Metodologia symboliczno-alegorycznej interpretacji Biblii oraz jej teologiczne i duszpasterskie zastosowanie, Warszawa 2007, s. 80; A. Eckmann, Pismo święte w życiu i nauczaniu Ojców Kościoła, AK 71 (1979), s. 205.

2 Ambrosius, De officiis ministrorum, 1,31,164, tłum. K. Abgarowicz, w: Święty Ambroży z Mediolanu, Obowiązki duchownych, Warszawa 1967, s. 77.

3 K. Bardski, dz. cyt., s. 80.

4 C. Corsato, Biblia w interpretacji Ojców Kościoła, Kraków 2007, s. 188-189. Posiadanie tej umiejętności poświadcza również świadectwo Augustyna, które zostało ukazane w: A. Eckmann, Św. Ambroży jako duchowy mistrz św. Augustyna, Vox Patrum 18 (1998), s. 195-198.

5 Ch. Kannengiesser, Handbook of Patristic Exegesis. The Bible In Ancient Christianity, Leiden-Boston 2006, s. 1045. 
Szczególnym zainteresowaniem biskupa Mediolanu cieszył się Stary Testament. W swoich wywodach chętnie odnosił się do wydarzeń tam opisanych, które najczęściej objaśniał w odniesieniu do osoby Jezusa Chrystusa, dlatego uważa się, że w jego dziełach przeważa interpretacja alegoryczna lub typologiczna. Trzeba jednak zauważyć, że Ambroży nie stronił od interpretacji moralnej czy też wyrazowej.

W niniejszym artykule będziemy analizowali sposób wykorzystania Księgi proroka Jonasza w nauczaniu biskupa Mediolanu. Badaniu zostaną poddane wszystkie $^{6}$ fragmenty odnoszące się do tej właśnie księgi zawarte w dziełach Ambrożego. Kolejność analizowanych pism została przyjęta na podstawie prawdopodobnej daty ich powstania przyjętej przez Kannengiessera ${ }^{7}$.

\section{Expositio Euangelii secundum Lucam}

Jest to jedyny komentarz poświęcony Nowemu Testamentowi wśród pism egzegetycznych Ambrożego. Składa się na nie mniej więcej 25 kazań i kilka rozpraw. Homilie te są jednak przeredagowane tak bardzo, że zdecydowanie odbiegają od swojej pierwotnej formy. W swoich rozważaniach Ambroży poszukuje w tekście potrójnego sensu biblijnego: wyrazowego (historycznego), moralnego (praktycznego) oraz alegorycznego (mistycznego). Często też zauważa w rozważanym tekście sens typiczny ${ }^{8}$.

Ambroży, rozważając tekst Łk 11,29-54 mówiący o winie faryzeuszów, rozpoczyna w następujący sposób:

Abyś wiedział, że wraz z pochwałą udzieloną Kościołowi lud Synagogi otrzymał naganę, dodał: „To plemię jest plemieniem przewrotnym, znaku szuka, a znak nie będzie mu dany, jeno znak Jonasza proroka. Albowiem jak Jonasz był znakiem dla Niniwitów, tak Syn Człowieczy będzie znakiem”. I te słowa wyrażają naganę dla żydowskiego ludu i jasno wskazują na tajemnicę Kościoła. Ten w postaci Niniwitów przez ich pokutę i w postaci królowej ze Wschodu, która przybyła dla nabycia mądrości, aby poznać słowa miłującego pokój Salomona, jest zebrany z granic całego świata. Jest zaprawdę królową, bo jej królestwo jest niepodzielne, zebrane w jedno z różnych ludów od siebie oddalonych. I tak: „tajemnica ta wielka jest co do Chrystusa i Kościoła”. Większa jest od tej, która w figurze poprzedzała tą, która teraz z całą prawdą się spełniła. Tam bowiem Salomon był figurą, tu Chrystus jest w swoim

6 Ustalenie listy tekstów na podstawie: Biblia Patristica. Index des citations et allusions bibliques dans la littérature patristique. T. 6. Hilaire de Poitiers. Ambroise de Milan. Ambrosiaster, Paris 1995, s. 93 oraz komputerowej wersji Patrologia Latinae.

7 Ch. Kannengiesser, dz. cyt., s. 1047-1070.

8 A. Bogucki, Wstęp, w: Św. Ambroży, Wykład Ewangelii według św. Łukasza, PSP 16, Warszawa 1977, s. 9-15; B. Altaner, A. Stuiber, Patrologia. Życie, pisma i nauka Ojców Kościoła, Warszawa 1990, s. 504; F. Drączkowski, Patrologia, Pelplin-Lublin 1999, s. 321. 
ciele. Z dwojga więc Kościół się składa: z tego, aby nie znał grzechu lub przestał grzeszyć. Pokuta bowiem winę usuwa, mądrość przed nią broni. Tyle o mistycznym znaczeniu"9.

Jak zaznacza sam autor, mamy w tym tekście do czynienia $\mathrm{z}$ ukazaniem sensu alegorycznego wydarzeń opisanych w Księdze proroka Jonasza. Mieszkańcy Niniwy oraz królowa ze Wschodu są obrazem Kościoła, który poszukuje Chrystusa. Ambroży wykorzystuje również w tym tekście sens moralny, wskazując na postępowanie postaci starotestamentalnych, które może być wzorem dla innych.

Do osoby proroka biskup Mediolanu powraca jeszcze raz w następujących słowach: „Zresztą znak Jonasza jest figurą męki Pana, jest też zarazem świadectwem ciężkich grzechów, jakie Żydzi popełnili. Można się też w nim dopatrywać powagi słów i miłosierdzia (Boga). O ile bowiem idzie o Niniwitów, to przedstawiona jest tu kara (jaka ich czeka), a i lekarstwo na nią. Toteż i Żydzi nie powinni rozpaczać, iż nie dostąpią przebaczenia, byleby chcieli pokutować"10. Widać w tym tekście typiczne rozumienie „znaku Jonasza”, które prowadzi Ambrożego do bardzo praktycznych wniosków wskazujących na dostępność przebaczenia ofiarowanego przez Boga dla wszystkich.

\section{De Helia et ieiunio}

Traktat ten składa się z homilii wygłoszonych do katechumenów podczas Wielkiego Postu. Tworzą do dwie części. Pierwsza odnosi się do postu i jest oparta na jednej z homilii Bazylego. Natomiast druga koncentruje się na problemie, jakim jest pijaństwo i brak umiaru. Jest ona również oparta na dziełach Bazylego. Trzeba jednak zauważyć, że cały traktat bardzo obficie czerpie z Biblii. Nieustannie spotykamy się z cytatami z Pisma Świętego lub parafrazami tekstu biblijnego $^{11}$.

W drugiej części traktatu, w miejscu, w którym Ambroży komentuje Iz 23,2-3, znajdujemy odniesienie do Księgi proroka Jonasza. Ukazując niebezpieczeństwa żeglugi, odwołuje się on do nakazu panowania nad stworzeniem zawartego w pierwszym opisie stworzenia świata ( $\operatorname{Rdz} 1,28)$, w którym nie ma mowy o żeglowaniu. Jako kolejny argument zostaje przytoczony interesujący nas tekst: „W końcu i prorok Jonasz posłany do Niniwy, aby głosić pokutę,

9 Ambrosius, Expositio Euangelii secundum Lucam, 7,96, tłum. W. Szołdrski, w: Św. Ambroży, Wykład Ewangelii według św. Łukasza, PSP 16, s. 289-290.

10 Ambrosius, Expositio Euangelii secundum Lucam, 7,97, tłum. W. Szołdrski, w: Św. Ambroży, Wykład Ewangelii według św. Łukasza, PSP 16, s. 290.

11 P. Jędrzejewski, Św. Ambroży z Mediolanu. O Eliaszu i poście (De Elia et ieiunio). Wstęp, VoxP 18 (1998), s. 472. 
z tego powodu, że chciał wypływać w morze, aby umknąć sprzed oblicza Bożego, został zaskoczony przez burzę, i wskazany losem rzucony w morze, a następnie połknięty przez wieloryba" ${ }^{12}$. Mamy tu do czynienia $\mathrm{z}$ wykorzystaniem przez Ambrożego sensu wyrazowego tekstu biblijnego dla potwierdzenia postawionej wcześniej tezy.

\section{De interpellatione lob et David}

Dzieło to składa się z czterech homilii odnoszących się do Księgi Hioba oraz do sytuacji króla Dawida ukazanej na podstawie psalmów. Analizowane cytaty z Księgi Psalmów z jednej strony podkreślają kruchość ludzkiego życia, a z drugiej - szczęście i powodzenie niesprawiedliwych ${ }^{13}$.

W rozdziale szóstym drugiej księgi noszącej tytuł De interpellatione David Ambroży najpierw ukazuje skarżącego się Dawida, którego dotykają nieszczęścia ze względu na popełnione grzechy. Następnie, ukazując kwestię wybrania przez Boga już w łonie matki, wskazuje na teksty biblijne mówiące o opiece ze strony Boga już od poczęcia, odnosząc je do osoby Jezusa. Wśród postaci biblijnych zostaje przywołany również interesujący nas prorok: „Z tobą byłem, który tak jak Jonasz w brzuchu wieloryba znajdowałeś się, ty błagający za ludem"14.

\section{De paenitentia}

Bardzo krótką wzmiankę dotyczącą Księgi Jonasza znajdujemy w jednym z traktatów dogmatycznych, w którym została poruszona tematyka nawrócenia i pokuty. Ambroży przeciwstawia się rygoryzmowi Nowacjana, ukazując, że Kościół katolicki ma władzę odpuszczania grzechów ${ }^{15}$. Na podstawie tego dzieła można zapoznać się z praktykami pokutnymi, jakie miały miejsce $\mathrm{w}$ Mediolanie w IV wieku ${ }^{16}$.

Interesujący nas fragment znajduje się właśnie wśród opisów praktyk pokutnych. Dla Ambrożego płacz jest zewnętrznym przejawem podjętej pokuty. Wśród postaci biblijnych, które mają uzasadniać taką właśnie postawę, na pierwszym miejscu wymienia on mieszkańców Niniwy: „Tak płakał również lud w Niniwie i uniknął zapowiedzianej zagłady miasta; tak wielkim jest bowiem lekarstwem

12 Ambrosius, De Helia et ieiunio, 19,70, tłum. P. Jędrzejewski, w: Św. Ambroży z Mediolanu. O Eliaszu i poście (De Elia et ieiunio), Vox Patrum 18 (1998), s. 494.

13 M.G. Mara, Ambrose of Milan, Ambrosiaster and Nicetas, w: Patrology, t. IV, red. A. di Berardino, Notre Dame 1986, s. 161.

14 Ambrosius, De interpellatione Iob et David, 2,6,25, PL 14, k. 821.

15 B. Altaner, A. Stuiber, dz. cyt., s. 506; C. A. Guryn, Wstęp, w: Św. Ambroży, Wybór pism, PSP 7, Warszawa 1971, s. 9-12.

16 M.G. Mara, dz. cyt., s. 173. 
pokuta, iż Bóg zdaje się zmieniać swój wyrok. Od ciebie więc zależy, abyś go uniknął". ${ }^{17}$ Biskup Mediolanu w tym miejscu interpretuje tekst biblijny literalnie, poprzestając na jego znaczeniu dosłownym, które jest wystarczające do uzasadnienia wysuniętej przez niego tezy.

\section{Expositio de Psalmo CXVIII}

Spotykamy tu przykład bardzo rozbudowanego komentarza do Psalmu $118^{18}$. Składa się on z 22 homilii, odpowiadających 22 strofom tego psalmu. Ukazana jest w nim przemiana i dojrzewanie duszy ludzkiej (Oblubienicy) do zjednoczenia z Chrystusem (Oblubieńcem), a także analogiczna relacja Kościół-Chrystus. Ambroży, pisząc o nawróceniu duszy, stosuje egzegezę typu moralnego, natomiast w odniesieniu do Kościoła - typologiczną. Dzieło to powstało w latach $386-388^{19}$.

Komentując 18 zwrotkę tego psalmu, której wersety rozpoczynają się od litery sade, Ambroży rozważa postępowanie sprawiedliwego znajdującego się w niebezpieczeństwie, który przyjmuje postawę wychwalającą Boga. Za przykłady takiego postępowania służą mu różne postacie biblijne, wśród nich wspomniany jest również Jonasz. Sytuację dotyczącą jego postępowania przedstawia w następujących słowach: „Jonasz uwięziony w brzuchu bestii, pragnący oddechu $\mathrm{z}$ trudem przychodzącego, sprawiedliwy niesprawiedliwym losem skazany, wykrzyknął z brzucha wieloryba w morzu: głosem pochwalnym i z przyznaniem się do winy pokornie błagam Ciebie"20. Przywołano tu fragment hymnu pochwalnego wygłoszonego przez proroka w brzuchu ryby, którego dosłowna interpretacja potwierdza założenie Ambrożego.

\section{Hexaemeron}

Dzieło to składa się z dziewięciu homilii zgrupowanych w sześć ksiąg. Były one wygłaszane $\mathrm{w}$ kolejnych dniach Wielkiego Tygodnia, miejsce na przestrzeni lat 386-39021. Teksty te odnoszą się do opisu stworzenia świata zawartego w Rdz 1,1-26. Ambroży wykorzystał utwór o tym samym tytule autorstwa Bazylego Wielkiego oraz, jak twierdzi Hieronim, komentarze Orygenesa

17 Ambrosius, De paenitentia, 2,6,48, tłum. W. Szołdrski, w: Św. Ambroży, Wybór pism, PSP 7, s. 70.

18 Numeracja psalmów w całym artykule za Septuagintą, ponieważ taką stosował w swoich pismach Ambroży.

19 Ch. Kannengiesser, dz. cyt., s. 1060; J. Czuj, Wstęp, w: Św. Ambroży, Mowy, POK 21, Poznań 1939, s. 12; F. Drączkowski, dz. cyt., s. 320-321.

20 Ambrosius, Expositio de Psalmo CXVIII, 18,6, PL 15, k. 1454.

21 M.G. Mara, dz. cyt., s. 153. 
i Hipolita Rzymskiego. Można w tym dziele odnaleźć również naleciałości pochodzące z tekstów klasycznych, m.in. Cycerona, Filona czy Wergiliusza ${ }^{22}$. Manilo Simonetti wskazuje, że zależność od Bazylego spowodowała, że w tym dziele Ambroży jest bardziej literalistą, choć nie tak skrajnym, jak jego prekursor ${ }^{23}$. Utwór ten ma w miarę wyraźny charakter tekstu mówionego.

W księdze czwartej poświęconej analogicznie czwartemu dniu stworzenia Ambroży polemizuje m.in. z poglądami astrologów, którzy na podstawie układów ciał niebieskich przy narodzeniu człowieka próbują określać, jaka przyszłość go czeka. Za jeden $\mathrm{z}$ argumentów posłużyły mu wydarzenia związane $\mathrm{z}$ interesującym nas prorokiem. „Jonasza rzuciła w morze nie moc jego urodzenia, ale grzech, jaki popełnił nie będąc posłuszny nakazowi Bożemu. Potwór morski połknął go i po trzech dniach wyrzucił z powrotem ze siebie, na znak przyszłej tajemnicy i zachował mu zasługi jako proroka"24. Ambroży w tym przypadku nie poprzestaje na potwierdzeniu postawionej tezy, ale czyni również delikatną aluzję o tajemnicy. W ten sposób czytelnik mógł w postaci Jonasza doszukać się czegoś więcej - w pewien sposób jest to zapowiedź dalszych rozważań na temat tej postaci, gdzie prorok będzie ukazany jako typ Chrystusa.

W księdze piątej poświęconej kolejnemu dniu stworzenia Ambroży najpierw w jednej homilii porusza kwestię ożywienia wód, a następnie w drugiej - świat ptaków. Po omówieniu różnych gatunków ryb i miejsca ich życia, w zakończeniu tej homilii po rozważaniach nad wielkością i pięknem Atlantyku Ambroży przechodzi do ukazania swoim słuchaczom osoby Jonasza, czym kończy. Interesujący nas fragment brzmi następująco:

Cóż powiem godnego o Jonaszu, którego wieloryb połknął aby mu ratować życie i zwrócił, aby się wywiązał z obowiązku proroka. Woda poprawiła tego, którego sprawy ziemskie sprowadziły z należytej drogi. Ten, który smucił się na lądzie śpiewał w brzuchu wieloryba. Aby nie pominięto niesienia ocalenia żadnego z żywiołów, ratunek (Jonasza) na morzu poprzedził uratowanie (Niniwitów) na lądzie. Znak Jonasza jest bowiem znakiem Syna człowieczego. Jak Jonasz przebywał w brzuchu wieloryba, tak Jezus w sercu ziemi. W obydwu ratunek. Większy jednak przykład pobożności dało morze, bo ryby przyjęły tego, którego odrzucili ludzie i tego, którego ludzie ukrzyżowali ryby zachowały. Piotr zachwiał się na morzu lecz nie upadł, a choć wyznał Pana na falach, jednak zaparł się go na lądzie. Tam okazując się pobożnym został ręką Pana pochwycony, tu ponieważ zapomniał się ściągnął na siebie jego karcący wzrok. Prośmy jednak Pana, aby nasza mowa została wyrzucona na ląd jak Jonasz, aby nie miotała się dłużej w słownych falach. Dobrze, że wyrósł

22 A. Bogucki, Wstęp, w: Św. Ambroży, Hexaemeron, PSP 4, Warszawa 1969, s. 16-17.

23 M. Simonetti, Między alegoria a dosłownością. Przyczynek do historii egzegezy patrystycznej, Kraków 2000, s. 280-281.

24 Ambrosius, Hexaemeron, 4,4,13, tłum. W. Szołdrski, w: Św. Ambroży, Hexaemeron, PSP 4, s. 123. 
bluszcz, aby osłaniać nas od naszych przewinień, ale to że usechł pod działaniem wschodzącego słońca pobudza nas do wypoczynku, aby umysł nasz nie począł się chwiać na lądzie, aby nie zabrakło nam słów. To jednak pewne, że bardziej nam niż Niniwitom udzielono przez wodę chrztu przebaczania grzechów ${ }^{25}$.

Historia Jonasza pobudza Ambrożego do wieloaspektowych przemyśleń. Zwraca on uwagę na typologię Jonasz-Chrystus, do której wielokrotnie nawiązuje. Nie do końca jasna jest wypowiedź o rybach, które zachowały ukrzyżowanego. Najprawdopodobniej chodzi tu o wierzących chrześcijan, którzy w swoim życiu i nauczaniu zachowali słowa Zbawiciela. Bardzo ciekawa jest interpretacja krzewu, który wyrósł dla Jonasza, a następnie usechł - ma on chronić od złego postępowania.

Podobnie w zakończeniu homilii poświęconej ptakom i jednocześnie w zakończeniu księgi piątej pojawia się wzmianka odnosząca się do proroka Jonasza: „Igraliśmy z ptakami, śpiewaliśmy z kogutem, dlatego wyśpiewujemy już tajemnicę Pana. Niech przystąpią do ciała Jezusa orły odnowione przez obmycie z grzechów. Już nam wieloryb zwrócił prawdziwego Jonasza i cieszymy się, że dzisiaj wieczorem skończył się dla nas dzień piąty" ${ }^{26}$. Tekst ten następuje po modlitwie i jest zapowiedzią bliskiego spotkania z Jezusem w komunii św., a jednocześnie ponownie wskazuje na typologię Jonasz-Chrystus.

\section{De fuga saeculi}

Jedno z pism egzegetycznych Ambrożego oparte na opisie miast ucieczki z Lb 35,11-34 oraz na dwóch dziełach Filona z Aleksandrii: Legum allegoriae oraz De fuga et inventione ${ }^{27}$. H. Savon stwierdza, że „ze wszystkich esejów Ambrożego bazujących na Filonie De fuga saeculi jawi się jako najbardziej oryginalny i wolny w odniesieniu do swojego pierwowzoru"28.

W dziele tym w sposób alegoryczny miasta ucieczki są ukazane jako wezwanie chrześcijan do oderwania się od dóbr tego świata i zwrócenia się do Chrystusa. Autor podaje różne teksty biblijne dotyczące postaci, zwłaszcza starotestamentalnych, które potwierdzają to wezwanie. W opisie dotyczącym Jakuba jego ucieczki przed gniewem brata, a następnie walki z Labanem - pojawiają się różne postacie biblijne, które mają być wzorem podobnej postawy. Wśród osób, które uciekały, obok m.in. Mojżesza i Dawida, pojawia się również Jonasz

25 Ambrosius, Hexaemeron, 5,11,35, tłum. W. Szołdrski, w: Św. Ambroży, Hexaemeron, PSP 4, s. 160.

26 Ambrosius, Hexaemeron, 5,25,92, tłum. W. Szołdrski, w: Św. Ambroży, Hexaemeron, PSP 4, s. 186.

27 Ch. Kannengiesser, dz. cyt., s. 1062; M.G. Mara, dz. cyt., s. 158.

28 Cytat za: Ch. Kannengiesser, dz. cyt., s. 1062. 
w następującym stwierdzeniu: „Odważam się powiedzieć, iż także Jonasz uciekł do Tarsu nie ciałem lecz wzniesieniem ducha. Wzniósł się do upodobnienia się z Chrystusem; stał się figurą Chrystusa. Albowiem jako był Jonasz w żywocie wielkiej ryby trzy dni i trzy noce - rzekł Jezus - tak i Syn Człowieczy będzie w sercu ziemi przez trzy dni i przez trzy noce. Gdyby nie uciekł, z wnętrza wielkiej ryby nie słyszano by go nigdy" 29 . Interpretacja opowiadania o Jonaszu, jakiej dokonuje Ambroży, może dziwić, ponieważ według niego ucieczka do Tarszisz (Tarsu w powyższym tłumaczeniu) jest elementem pozytywnym, który powoduje upodobnienie do Chrystusa. Z lektury tekstu biblijnego wiemy, że był to wyraz sprzeciwu wobec woli Boga. Jednak biskup Mediolanu kładzie akcent nie tyle na woli Jonasza, ile na planie Boga, który z tego czynu proroka wyciąga pozytywne konsekwencje. Dla Ambrożego najważniejszy jest pobyt Jonasza w brzuchu wielkiej ryby, który jest zapowiedzią trzech dni spędzonych w grobie przez Jezusa i Jego zmartwychwstania. Autor stwierdza, że gdyby nie ucieczka proroka, ten znak by nie zaistniał. Tak więc z postaci, która ma być przykładem uciekającego człowieka, Jonasz w rozważaniach Ambrożego przekształcił się w typ Chrystusa.

\section{Expositio super Psalmos XII}

Dzieło to jest komentarzem do dwunastu psalmów (Ps 1; 35-40; 43; 45; 47-48; 61), z czego komentarz do Psalmu 43 pozostał niedokończony ze względu na śmierć Ambrożego. Komentarze te są przepracowanymi homiliami. Według Kannengiessera, w ich wyborze jest bardzo wyraźnie zawarta linia nauczania biskupa Mediolanu. Rozpoczyna się od wezwania do nawrócenia (Ps 37), następnie czytelnik zostaje wprowadzony w chrystologiczne centrum nauczania (Ps 38-39) prowadzące do liturgii chrztu i eucharystii, gdzie jest zapewniona edukacja w wierze dorosłych (Ps 40-43), która z kolei przygotowuje wierzących

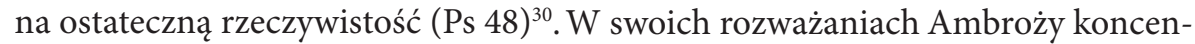
truje się nie tylko na charakterze mesjanistycznym treści zawartych w analizowanych psalmach, jednocześnie ukazuje bowiem zawarte w nich przesłanie moralne, które bardzo mocno osadza we współczesnej mu rzeczywistości kościelnej i politycznej ${ }^{31}$. Dla naszych rozważań ważne są dwa z nich, czyli komentarze do Psalmów 43 i 47.

W komentarzu do pierwszego z nich Ambroży, jak zaznacza na wstępie, zajmuje się Męką Pańską, misterium chrztu oraz „dostępem do ołtarza świętego”,

29 Ambrosius, De fuga saeculi, 4,19, tłum. W. Szołdrski, w: Św. Ambroży, Wybór pism, PSP 7, s. 103-104.

30 Ch. Kannengiesser, dz. cyt., s. 1067.

31 M.G. Mara, dz. cyt., s. 163. 
czyli eucharystią ${ }^{32}$. Rozważania nad w. 23 Psalmu 43 doprowadziły Ambrożego do ukazania proroka Jonasza jako figury zapowiadającej mękę Jezusa:

Zobacz raz jeszcze, czym różni się od Ewangelii to, co czytamy o Jonaszu, który spał we wnętrzu statku i chrapał. W nim jest figura zapowiedzi świętej męki. Podobnie jak Jonasz spał w łodzi i chrapał bezpieczny, jakby nie obawiając się odkrycia, tak Pan nasz, Jezus Chrystus, który figurę tę $\mathrm{w}$ tajemnicy swojej śmierci wypełnił, w Ewangelii spał. I podobnie jak ten trzy dni i trzy noce był w brzuchu wieloryba, tak Syn Człowieczy trzy dni i trzy noce był w sercu ziemi, w męce swojego ciała. Uczniów nawiedził ten, który gdy zbudził się ze śmierci i snu, odpoczynku swojego ciała, aby dla zbawienia świata zmartwychwstać. A zatem oto jest prawdziwy Jonasz, który naraził wybawienie duszy swojej dla nas. W tym celu więc podniesiony i wrzucony jest w morze ten, który w brzuchu wieloryba przebywał, pochwycony i połknięty przez niego, następnie z jego wnętrzności został usunięty. O jakim wielorybie to może być powiedziane, posłuchaj Hioba mówiącego: Kto może, rzecze, wielkiego wieloryba w niewolę oddać. Kto to jest? Bez wątpienia poznasz z tego, co było czytane, że Pan nasz, Jezus Chrystus, pochwycony prowadził uwięzionych, pokonawszy przeciwnika i wroga. Zatem my, którzy byliśmy uwięzieni, zaczęliśmy posiadać wolność dzięki Chrystusowi ${ }^{33}$.

Ambroży porównuje pobyt Jonasza w brzuchu ryby do czasu, który Jezus spędził w grobie. Dzieło zbawienia dokonane przez Chrystusa jest ukazane jako wielokrotnie przewyższające zapowiedź, która pojawiła się mgliście na przykładzie życia proroka.

W dalszych rozważaniach Ambroży zatrzymuje się nad treścią modlitwy proroka, w której odczytuje głębsze znaczenie odnoszące się do Jezusa.

Wreszcie sama modlitwa świętego Jonasza ukazuje, że męka Pańska jest tajemnicą, gdy mówi: Głośno wołam, rzecze, do Pana mego w ucisku moim i usłyszy mnie $\mathrm{z}$ wnętrza piekła. Widzisz, że to $\mathrm{z}$ wnętrza piekła mówi, a nie wieloryba? Pan zatem nie w wieloryba, lecz do piekła zstąpił. Jak i ci, którzy w piekle byli, z trwających ciągle więzów zostali wyzwoleni. Wreszcie wielka ich liczba znowu zmartwychwstała. Jaką zatem rzeką został otoczony Jonasz albo o jakiej otchłani mówił Jonasz: otchłań otacza mnie największa, zanurza się głowa moja w szczelinach gór. Zstąpiłem w ziemię, której zasuwami są kontynenty trwające wiecznie? Z pewnością to do osoby Jonasza nie pasuje, ani nie jest odpowiednie. To przecież Syn Boży zstąpił w szczeliny gór, gdy zstąpił do grobu ${ }^{34}$.

Dla Ambrożego modlitwa Jonasza w brzuchu ryby zawiera bardzo wyraźne aluzje, które mogą właściwie być zrozumiane jedynie w kontekście życia i misji

32 Por. Ambrosius, Expositio super Psalmos XII, 43,1, PL 14, k. 1087.

33 Ambrosius, Expositio super Psalmos XII, 43,83, PL 14, k. 1129.

34 Ambrosius, Expositio super Psalmos XII, 43,84, PL 14, k. 1129-1130. 
Jezusa. Zdaniem biskupa Mediolanu, nie są one zrozumiałe, jeśli próbujemy je odnieść do życia opisywanej postaci biblijnej.

Obraz proroka jako figury Zbawiciela powraca jeszcze raz w słowach: „Podobnie jak Jonasz wrzucony został w morze, i odpoczęło morze od wzburzenia swego. Tak Pan nasz Jezus Chrystus przyszedł na ten świat, aby świat odzyskać i krwią swoją wszystko uspokoić, zarówno ziemię, jak i niebo" ${ }^{35}$.

Pojawiająca się w w. 8 Psalmu 47 nazwa Tarszisz sprowokowała Ambrożego do krótkiej informacji: „Do niego spieszył Jonasz” ${ }^{\text {. }}$. Prorok pojawia się tu jako jedna $\mathrm{z}$ osób, które w Biblii są związane $\mathrm{w}$ jakiś sposób $\mathrm{z}$ tą miejscowością.

W zakończeniu swoich refleksji dotyczących tego psalmu Ambroży jeszcze raz przywołuje Księgę proroka Jonasza. Czyni to w rozważaniach nad kończącymi psalm wersetami (14 i 15), gdzie zostaje zacytowany fragment $z$ Ewangelii wg św. Mateusza: „Z tego powodu odpowiedział Pan: «Pokolenie zepsute i cudzołożne znaku żąda i żaden znak nie będzie mu dany poza prorokiem Jonaszem» (Mt 12,39). Do odsłonięcia więc przewrotności Żydów Jonasza przykład został przywołany. $Z$ tego powodu, że Niniwici znakowi uwierzyli i następnie przepowiadanie Jonasza, który był w brzuchu wieloryba, przyjęli. Żydzi natomiast nie uwierzyli po zmartwychwstaniu Pana Jezusa, który z serca ziemi po trzech dniach powstał i żyje panujący na wieki wieków. Amen"37. Ambroży w tym miejscu podkreśla zasługę mieszkańców Niniwy, aby uwypuklić niewiarę Żydów, którzy mieli do czynienia nie z jednym z proroków, ale z samym Zbawicielem, a mimo to nie uwierzyli.

\section{Epistulae}

W liście napisanym do swojej siostry Marceliny Ambroży opisuje wydarzenia związane ze sporem o bazylikę w Mediolanie pomiędzy arianami i katolikami. Rozgrywały się one przed Wielkanocą $385 \mathrm{r}^{38} \mathrm{~W}$ ich opisie Ambroży relacjonuje również swoje kazania, które wówczas wygłosił. Bardzo ciekawe jest wykorzystanie sytuacyjno-typologiczne tekstu biblijnego, który był czytany w tym czasie:

Zgodnie ze zwyczajem w tym dniu była czytana Księga Jonasza. Gdy skończono czytanie, powiedziałem takie kazanie: Bracia, księga, którą czytaliśmy, zapowiada, że grzesznicy w pokucie nawrócą się. Akceptowana jest ona bowiem, gdyż to, co ma się wydarzyć pokazuje w teraźniejszości. Dodam, jaki zatem mąż sprawiedliwy będzie chciał narażać się na winę, najpierw nie zobaczywszy ani nie ogłosiwszy

35 Ambrosius, Expositio super Psalmos XII, 43,85, PL 14, k. 1130.

36 Ambrosius, Expositio super Psalmos XII, 47,14, PL 14, k. 1151.

37 Ambrosius, Expositio super Psalmos XII, 47,25, PL 14, k. 1156.

38 J. Naumowicz, Wstęp, w: Św. Ambroży z Mediolanu, Listy, t. 1, BOK 9, Kraków 1997, s. 18. 
zagłady miasta. A ponieważ wyrok ten był złowrogi, zasmucony siedział również z powodu krzaku dyni ${ }^{39}$, który usechł. Wtedy również Bóg powiedział do proroka: czy jesteś smutny z powodu dyni? Jonasz odpowiedział: tak, jestem smutny. Powiedział Pan: jeśli oto cierpisz, ponieważ uschła dynia, czyż nie większa powinna być moja troska o zbawienie tak licznego ludu. I dlatego oddalił [Bóg] zniszczenie, które było przygotowane dla całego miasta ${ }^{40}$.

Po tym omówieniu swojego kazania Ambroży stwierdza, że bez żadnego dalszego opóźnienia bazylika z rozkazu Cesarza została oddana katolikom i pisze o wielkiej radości ludu $\mathrm{z}$ tego powodu. ${ }^{41}$ Widać $\mathrm{w}$ tym tekście, jak biskup Mediolanu interpretuje fakt ocalenia Niniwy jako zapowiedź odzyskania kościoła przez wiernych. Choć trudno mówić o podobieństwie sytuacji, to jednak dla Ambrożego fakt postu i modlitwy mediolańczyków jest wystarczającym powodem, żeby mogli doświadczyć pomocy ze strony Boga, który, jak podkreśla to w swoim kazaniu, jest litościwy dla cierpienia tak licznego ludu.

W liście do papieża Syrycjusza Ambroży dziękuje za troskę z jego strony oraz informuje, że idąc za jego przykładem, synod w Mediolanie potępił herezję Jowiniana $^{42}$. W treści listu przytacza on poglądy herezjarchy i jednocześnie podaje argumenty biblijne wskazujące na błędność jego nauki. Omawiając kwestię postu zachowywanego przez wdowy, którego sens i pożytek Jowinian krytykował, Ambroży przywołuje najpierw nauczanie św. Pawła, a następnie proroków. Jednym z argumentów jest przykład Niniwitów, jak pisze: „Niniwa przez post wyzwoliła się od śmierci" ${ }^{43}$. Tak więc po raz kolejny Ambroży wykorzystuje sens wyrazowy tekstu pochodzącego z Księgi proroka Jonasza dla potwierdzenia wcześniej postawionej tezy.

\section{Podsumowanie}

Na podstawie zaprezentowanych wyżej analiz poszczególnych dzieł Ambrożego, w których wykorzystuje on Księgę proroka Jonasza, możemy stwierdzić, że była ona mu bardzo dobrze znana. Musiał wielokrotnie do niej sięgać w swojej lekturze, o czym świadczy swoboda, z jaką z niej korzysta, oraz fakt pojawiania się odniesień do niej w bardzo różnych sytuacjach, nawet takich, które wprost nie wskazują na tę możliwość.

39 W tym miejscu pojawia się łac. cucurbita, które jest tłumaczeniem grec. ко $\lambda$ ó $v \nu \theta \alpha$ z Septuaginty. W tekście hebrajskim mamy w tym miejscu:! קיץין, co na język polski tłumaczone jest jako krzew rycynusowy.

40 Ambrosius, Epistulae, 20,25, PL 16, k. 1001-1002.

41 Ambrosius, Epistulae, 20,26, PL 16, k. 1002.

42 J. Naumowicz, dz. cyt., s. 22.

43 Ambrosius, Epistulae, 42,11, PL 16, k. 1028. 
W interpretacji stosowanej przez biskupa Mediolanu przeważa ukazanie Jonasza jako typu Chrystusa, ze szczególnym uwzględnieniem trzydniowego pobytu proroka w brzuchu ryby jako obrazu trzech dni przebywania przez Jezusa w grobie. Obok tej typologii Ambroży sięga również do postawy nawrócenia Niniwitów, czy to dla ukazania ich jako typu nawróconych pogan, czy też jako wzoru postępowania, akcentując ich gotowość do nawrócenia w kontraście z zatwardziałością Żydów. Nie brakuje również tekstów, w których dla potwierdzenia jakiejś tezy wystarcza sens wyrazowy wydarzeń opisanych w Księdze proroka Jonasza.

Warto również zwrócić uwagę na fakt, że dzieła, w których spotkaliśmy się z wykorzystaniem tekstów z interesującej nas księgi Starego Testamentu, mają bardzo różny charakter. Mamy wśród nich pisma stricte egzegetyczne i takie, które są do tej grupy zaliczane, choć ich treść ma bardziej wydźwięk moralno-ascetyczny. Znajdziemy wśród nich również jedno z pism dogmatycznych oraz listy. Taka sytuacja jeszcze raz potwierdza, że Ambroży wykorzystywał Pismo Święte jako główne źródło swojego nauczania i właśnie w nim szukał argumentów we wszelkiego rodzaju dyskusjach czy przemowach.

\section{Place of Book of Jonah in the teaching of Saint Ambrose}

\section{Summary}

Ambrose is known as a one who quoted very often the Holy Scripture. Among his writings there is many commentaries to books of the Old Testament. However the commentary to the Book of Jonah apparently does not exist. Although when we read very carefully his writings we can notice that this book was known to him very well. He used it in various situations to give reasons for his statements using a verbal sense of the biblical story. But the most frequent and important use of this book is reading it according to the typology of Christ. Besides these interpretations Ambrose showed moral sense of biblical text, especially with reference to the people of Nineveh, which conversion should be an example for others. 